$\xi^{2}=$ 国

\title{
Effect of dolomite amendment of acid Andosols on the performance of two green beans varieties in the Cameroon Western Highlands
}

\author{
Azinwi Tamfuh $\mathrm{P}^{1,2 *}$, Kamga Pangop $\mathrm{CR}^{3}$, Douanla Tapindje DG ${ }^{1}$, Boukong $\mathrm{A}^{1}$, Tabi FO ${ }^{1}$, \\ Cho-Ngwa $F^{1}$, Bitom $D^{1}$ \\ ${ }^{1}$ Department of soil science, Faculty of Agronomy and Agricultural Sciences, University of Dschang, P.O Box 222, Dschang, Cameroon \\ ${ }^{2}$ Department of Mining and Mineral Engineering, National Higher Polytechnic Institute, University of Bamenda, P.O Box 39, Bambili, \\ Cameroon \\ ${ }^{3}$ Production des Légumes SA, Foumbot, Cameroon \\ *Corresponding author E-mail:aprimus20@yahoo.co.uk
}

\begin{abstract}
Soil acidity is a major factor limiting green beans (Phaseolus vulgaris L.) production in the Cameroon western Highland. A field experiment (split-plot layout) was conducted with seven dolomite treatments (tons ha ${ }^{-1}$ ): control or $\mathrm{T}_{0}(0), \mathrm{T}_{1}(0.5), \mathrm{T}_{2}(1), \mathrm{T}_{3}(1.5), \mathrm{T}_{4}(2), \mathrm{T}_{5}$ (2.5) and $\mathrm{T}_{6}$ (3). Soil physico-chemical properties were determined meanwhile growth and yield parameters were collected weekly for a month and analyzed statistically. Results revealed that control soils were texturally silty sandy. The exchangeable bases (except Na), cation exchange capacity (CEC), base saturation and available phosphorus were very high. They acidity was moderate to high (5.2 to 5.6) while organic matter was very high (\% dry mass) and of moderate to good quality $(11<\mathrm{C} / \mathrm{N}$ ratio $<13)$. Crop variety showed a highly significant difference $(\mathrm{P}<0.001)$ for all growth and yield parameters, with Cogito producing the longest $(13.88 \mathrm{~cm})$, most numerous (40.94 pods per plant) and highest (16.96 tons ha $\left.{ }^{-1}\right)$ extrafine pods. Dolomite doses revealed no significant effects $(\mathrm{P}>0.05)$ on crop parameters, although highest yield (13.61 tons ha- ${ }^{-1}$ ) of extrafine pods came from 2 tons ha ${ }^{-1}$. The dolomite dose versus variety interaction showed no significant difference $(\mathrm{P}>0.05)$. Farmers ought to improve soils with compost and cover crops to check nutrient leaching and erosion.
\end{abstract}

Keywords: Phaseolus vulgaris L.; Dolomite amendment; Growth/yield parameters; Cameroon Western Highlands.

\section{Introduction}

Acid soils occupy about 3.95 billion hectares (30\%) of the total world arable soils (Von Uexkuel and Mutert 1995; Velasquez et al. 2008). In Africa, acid soils cover $25 \%$ of total arable land and about $75 \%$ in Cameroon (Bindzi 1987; Ambassa-Kiki et al. 2002). Soil acidification is characterized by the desaturation of the absorption complex principally in exchangeable cations (Calcium, magnesium and potassium) (Sama 1989; Duchaufour 1997; Tsozué et al. 2015; Azinwi Tamfuh et al. 2018). These acid soils are instead characterized by excess $\mathrm{Al}^{3+}$ and $\mathrm{H}^{+}$which inhibit plant root development and the absorption of essential plant nutrients (Brady and weil 2014). Several factors are at the origin of soil acidity amongst which the nature of the parent rock, climate, vegetation, farming methods (slash and burn, excessive use of acidic fertilizers, etc) (Soltner 1988; Ibrahim et al. 2002; Tabi et al. 2012; Muñoz-Sanchez et al. 2015). The consequences of soil acidity in developing countries are drop in yields estimated at 3 to 67\% (Borrero et al. 1995; Thé et al. 2001; Kamga et al. 2013; Opala et al. 2015; Bekele et al. 2018). In Cameroon, like most African Countries, demographic pressure on land has stirred counter season farming and fallow time reduction (Getachew et al. 2014). This situation has exposed soils to erosion and nutrient depletion. In effect, due to drastic soil acidification. The aluminium becomes toxic and can strongly compromise productivity (Ibrahim et al. 2012). Thus, continuous soil degradation is a constant preoccupation in Sub-Saharan Africa (Bindzi 1987; Ambassa-Kiki et al. 2002; Bekele et al. 2018). To maintain continuous crop production, the control of soil acidity is indispensable. In order to alleviate this problem, several solutions have been proposed like the use of lime or calco-magnesian fertilizers to buffer excess $\mathrm{H}^{+}$ions in soils (Thé et al. 2001; Kaho et al. 2007; Xiao et al 2016). Dolomite addition could mitigate the effects of acid rain (Allen and Brent 2001) and/or alleviation of soil acidification caused by agricultural fertilizer (Beernaert and Bitondo 1992; Teir et al. 2006). PROLEG S.A. is preoccupied to resolve the problem of soil acidity and to create favourable $\mathrm{pH}$ conditions for the growth and development of green beans, which according to Beernaert and Bitondo (1991) is 6-6.5 pH range. This is why this agricultural enterprise located in Foumbot (Cameroon Western Highlands) has resorted to the use of dolomite dust. In effect, a preliminary trial involving the use of $600 \mathrm{~kg} / \mathrm{ha}$ at soil $\mathrm{pH} 5.6 \mathrm{enabled}$ to obtain yield increments from 5 to 9 tons ha- 1 of the extrafine pods. Nevertheless, the correct application dose to provide optimum yield is unknown in this area. The aim of the present work was therefore to assess the effect of seven doses of dolomite dust on the grown and yield of two varieties of green beans. 


\section{Materials and methods}

\subsection{Study site}

The field experiment was conducted from $20^{\text {th }}$ April to 24 June 2017 in the West Region of Cameroon, precisely in PROLEG SA Foumbot. This town is situated at about $27 \mathrm{~km}$ north of Bafoussam Town (West Regional Headquarter) between latitude $05^{\circ} 30^{\prime}-05^{\circ} 42^{\prime}$ $\mathrm{N}$ and longitude $10^{\circ} 34^{\prime}-10^{\circ} 43^{\prime} \mathrm{E}$ (Fig. 1). The climate is the Cameroon type equatorial domain characterized by a dry season of four months (mid-November to mid-March) and a rainy season of eight months (mid-March to mid-November). Total average annual rainfall is $1600 \mathrm{~mm}$ and the mean annual temperature is $22^{\circ} \mathrm{C}$. Foumbot belongs to the Shrub savannah domain, characterized by Graminae with few trees and shrubs; the natural semi-deciduous forest only persists as remnants of swampy forest in the flooded plains and valleys (Letouzey 1985). The Precambrian basement composed of metamorphic rocks (gneiss and migmatite intruded by various granitoids) is covered by a thick layer of pyroclastic materials (Wandji 1985). On this pyroclastic material is formed a Leptic Andosol according to the world Referential Base (FAO-ISRIC 2006), as documented by Ngandeu Mboyo (2008). The Foumbot PROLEG Farm is located at the entrance of the Foumbot Town. It is specialized in the production of green beans and Maize. The farm stretches from latitude $5^{\circ} 29^{\prime}$ to $5^{\circ} 31^{\prime}$ 'Nord and from longitudes $10^{\circ} 36^{\prime}$ to $10^{\circ} 37^{\prime}$ East (Fig. 1). This zone is located in the Noun valley that separates the Bamileke plateau and the Bamoum Plateau which form the Cameroon Western Plateaus.

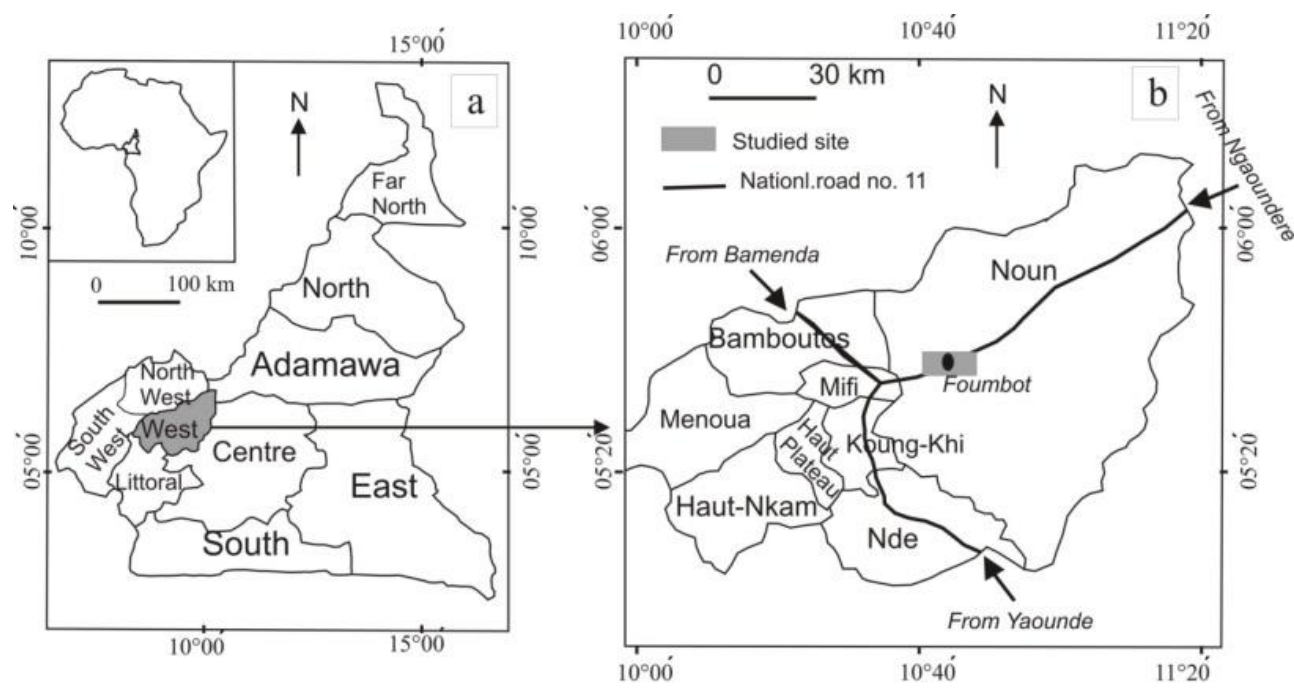

Fig. 1: Location of the Studied Site. (A) West Region in Cameroon; (B) Foumbot in the West Region.

\subsection{Methodology}

\subsubsection{Experimental design and land preparation}

Land preparation was done from the $10^{\text {th }}$ to $20^{\text {th }}$ of April 2017. It was comprised of weeding, deep tilling (20-30 cm) pegging, separation into blocks and experimental units and levelling of the beds. The experimental layout was a randomized complete block (split-plot) design with three replications (Fig. 2). Each block was composed of two rows each having seven experimental units (EUs). Each green beans variety was planted on one experimental row of a block (Fig. 2). All plant residues were removed during cultivation and irrigation was done to improve soil moisture before planting. The design was composed of 42 EUs each having a surface area of $6 \mathrm{~m}^{2}(3 \times 2 \mathrm{~m})$. The EUs were $1 \mathrm{~m}$ apart within the same block meanwhile blocks were separated by $1.5 \mathrm{~m}$ gap. Each EU was composed of four planting lines arranged perpendicularly to the length of the unit. Interline spacing was $80 \mathrm{~cm}$ and the plants were $7 \mathrm{~cm}$ apart on the same line. This corresponds to a planting density of 104 plants per EU, that is, 4368 plants for the 42 EUs on a total surface area of $252 \mathrm{~m}^{2}$ on planting beds. The total surface area of the experimental plot was $594 \mathrm{~m}^{2}$.

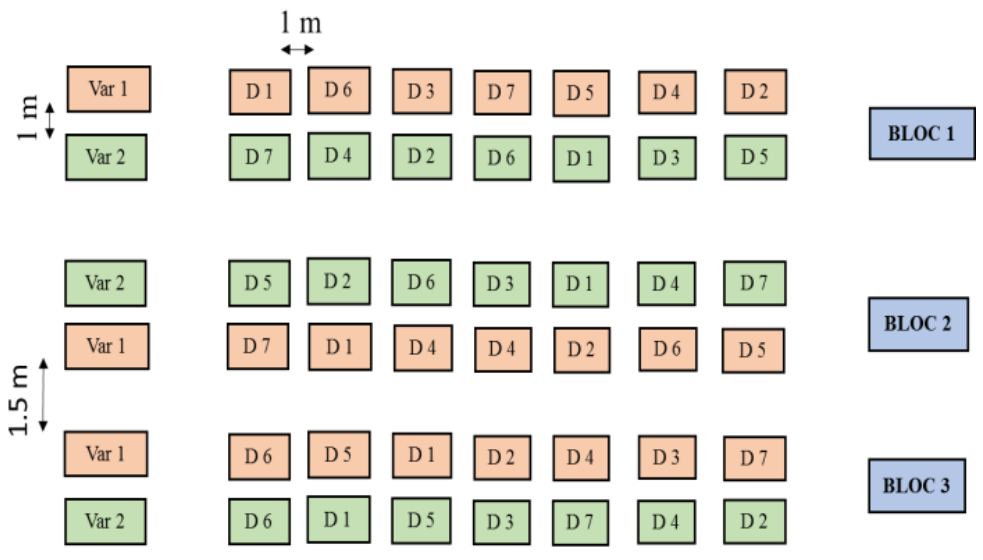

Fig. 2: Experimental Design (Var 1: Variety 1 or Morgan); Var 2: Variety 2 or Cogito). 


\subsubsection{Soil sample collection}

Before planting, one composite soil sample was collected at 0-20 cm depth (rooting zone) in each experimental block, stored in a clean plastic bag and taken to the laboratory for analysis.

\subsubsection{Dolomite application}

The dolomite doses per EU were calculated by simple proportion considering that the surface area of a block is $6 \mathrm{~m}^{2}(3 \mathrm{~m} \times 2 \mathrm{~m})$. The following seven dolomite doses were used: $0 \mathrm{~kg}$ for 0 tons ha ${ }^{-1}, 0.3 \mathrm{~kg}$ for 0.5 tons ha ${ }^{-1}, 0.6 \mathrm{~kg}$ for 1 tons ha ${ }^{-1}, 0.9 \mathrm{~kg}$ for 1.5 tons ha ${ }^{-1}, 1.2$ $\mathrm{kg}$ for 2 tons ha ${ }^{-1}, 1.5 \mathrm{~kg}$ for 2.5 tons ha- ${ }^{-1}$ and $1.8 \mathrm{~kg}$ for 3 tons ha ${ }^{-1}$. The total quantity of dolomite used in the experiment was $37.8 \mathrm{~kg}$. Doses were weighed using an electronic balance and stored in plastic sachets (42 sachets). The dolomite dust was then uniformly applied on each experimental unit and incorporated to a depth of $30 \mathrm{~cm}$.

\subsubsection{Planting and management}

Planting was done on $30^{\text {th }}$ April 2017. Pegging and tracing of planting lines where done for each EU. Planting holes of $30 \times 30 \times 30 \mathrm{~cm}$ were made by maintaining an inter row spacing of $80 \mathrm{~cm}$ and an intra row spacing of $30 \mathrm{~cm}$. Basal dressing (applied two days prior to seeds sowing) and all the crop management practices were on based recommendations of Anon (2003). Plant management involved the following soil softening, fertilizer application, and weeding, mulching and phyto-sanitary treatment. Surface soil softening beside the plant roots enabled to improve aeration for plant respiration and to facilitate downward movement of nutrients. This operation started two weeks after planting and was repeated each two weeks immediately before each fertilizer application. Three soil softening operations were performed corresponding to the number of fertilizer applications. The fertilizer application involved the addition of urea (46\% $\mathrm{N}$ ) after every two weeks immediately after the hoeing (week 2, week 4 and week 6). The urea was first fractionated into three equal doses $(1.512 \mathrm{~kg})$, and the quantities corresponding to each experimental unit (36 g) were weighed and stored in plastic sachets. Weeding was done manually. Mulching was done on the $16^{\text {th }}$ and $34^{\text {th }}$ days after planting. Phytosanitary treatment involved leaf spray using fungicides and insecticides after every seven days throughout the experiment in order to eliminate angular spots, rust and pests.

\subsubsection{Plant data collection}

Plant data collection started two weeks after planting and was repeated every one week for one month. The data was collected from 12 plants per EU, located at the centre of the middle lines of the EU ( 6 plants per line). Thus, plant height was measured using a graduated tape. The leaf area index was obtained as the product of leaf length $(\mathrm{cm})$, leaf width $(\mathrm{cm})$ and a constant $(0.75)$ (Jos et al. 2007). The collection of yield parameters started on the $13^{\text {th }}$ of June 2017 and was conducted on the same plants that served for the collection of growth parameters. Thus, gauging-rods bearing two holes of $5 \mathrm{~mm}$ and $6.5 \mathrm{~mm}$ (minimum and maximum diameters of extrafine pods, respectively) were used to calibrate the pods before harvesting. During this field operation, all the pods with diameters higher than the holes were harvested. The growth parameters collected include: Length of extrafine pods, number of extrafine pods, weight of extrafine pods, number of pods exceeding calibre, weight of pods exceeding calibre.

\subsubsection{Laboratory analyses}

The soil physico-chemical analyses were done at the "Laboratoire d'Analyse des Sols et de Chimie d'Environnement"(LABASCE) of the Faculty of Agronomy and Agricultural Sciences (FASA) of the University of Dschang (Cameroon). The soil relative humidity was determined by noting the weight-loss of an air-dried sample, after subjecting it to an oven temperature of $105^{\circ} \mathrm{C}$ for 24 hours (FAO 2006). The bulk density was determined in reference to Archimedes' principle and particle density was measured by pycnometer method (FAO 2006). Soil porosity was deduced from bulk density and particle density (FAO 2006). The particle size distribution was measured by Robinson's pipette method (FAO 20o6). The $\mathrm{pH}-\mathrm{H} 2 \mathrm{O}$ was determined in a soil/water ratio of 1:2.5 and the $\mathrm{pH}$ $\mathrm{KCl}$ was determined in a soil/ $\mathrm{KCl}$ composition of 1:2.5 (FAO 2006). The organic carbon (OC) was measured by Walkley-Black method (Walkley and Black 1934). Organic matter (OM) was obtained from organic carbon (OC) using the Sprengel factor as in equation (1934):

$$
\mathrm{OM}=\mathrm{OC} \times 1.724 \text {. }
$$

Total nitrogen (TN) was measured by the Kjeldahl method (Bremner and Mulvaney 1982). Available phosphorus was determined by concentrated nitric acid reduction method (Olsen and Sommers 1982). Exchangeable cations were analyzed by ammonium acetate extraction at pH7 (Thomas 1982). The cation exchange capacity was measured by sodium saturation method (Rhoades 1982). The base saturation was calculated as the percentage of the sum of exchangeable cations (S) divided by the cation exchange capacity (CEC).

\subsubsection{Statistical Analysis}

Statistical analysis was performed using the SPSS software program (SPSS Inc., Version 12.0). The data were analyzed by oneway analysis of variance (ANOVA). The Tukey's test was used to detect the statistical significance of differences $(\mathrm{P}<0.05)$ between means.

\section{Results}

\subsection{Soil characteristics before treatment}

The soils (0-30 cm depth) of the studied plot, before planting, showed a silty sandy texture at the surface (Table 1$)$. The $\mathrm{pH}-\mathrm{H}_{2} \mathrm{O}$ ranged between 5.2 and 5.6. The $\mathrm{pH}-\mathrm{KCl}$ ranged between 5 and 5.2. The potential acidity $(\Delta \mathrm{pH})$ varied between 0.1 and 0.3 . The organic carbon content also fluctuated between 4.76 and $6.01 \%$ dry mass. The total nitrogen ranged from 0.42 to $0.52 \%$. The $\mathrm{C} / \mathrm{N}$ ratio varied between 11 and 12. The exchangeable calcium and exchangeable $\mathrm{Mg}$ were between 11.11-15.3 cmolc kg-1 and 2.56-3.79 cmolc kg-1, respectively. The exchangeable $\mathrm{K}$ and exchangeable $\mathrm{Na}$ were lower $\left(1.34-1.70 \mathrm{cmolc} \mathrm{kg}^{-1}\right.$ for $\mathrm{K}$, and $0.01 \mathrm{cmolc} \mathrm{kg}^{-1}$ for Na). The sum of exchangea- 


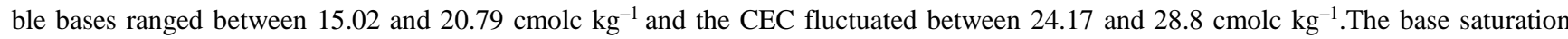
was greater than $60 \%$ for all the soils $(62.14$ and $72.5 \%)$. The available phosphorus ranged from 66.6 and $74.1 \%$. The Ca/Mg ratio varied from 3.56 to 3.34. The $\mathrm{Mg} / \mathrm{K}$ ratio fluctuated between 1.91 and 2.39 . The $\mathrm{Ca} / \mathrm{Mg} / \mathrm{K}$ ratio revealed an excess of $\mathrm{K}$ and $\mathrm{Mg}$ and a deficiency of $\mathrm{Ca}$ in all the soils compared to the ideal equilibrium condition of 76/18/6. The exchangeable sodium percentage was below $1 \%$.

\subsection{Study of growth parameters}

\subsubsection{Effect of variety on growth parameters}

The mean separations of plant height, leaf surface area and the number of leaves linked to the variation of the factor variety are shown in table 2. Thus, apart from leaf surface area, variety showed a highly significant $(\mathrm{P}<0.001)$ effect on all the growth parameters. As for plant height and the leaf surface area, Cogito was the most distinct with respective means of $39.26 \mathrm{~cm}^{2}$ and $21.54 \mathrm{~cm}^{2}$, respectively. Morgan recorded the highest means of plant height $(26.59 \mathrm{~cm})$ and number of leaves $(33.26)$ as well as the lowest mean leaf surface area $(18.21$ $\left.\mathrm{cm}^{2}\right)$.

Table 1: Soil Characteristics

\begin{tabular}{|c|c|c|c|c|}
\hline $\begin{array}{l}\text { Soil sample } \\
\text { Soil properties }\end{array}$ & & Block 1 & Block 2 & Block 3 \\
\hline Bulk density & & 0.83 & 0.86 & 0.86 \\
\hline \multirow{4}{*}{ Texture } & Sand & 71 & 64 & 67 \\
\hline & Silt & 22 & 26 & 24 \\
\hline & Clay & 7 & 10 & 9 \\
\hline & Textural class & Silty sand & Silty sand & Silty sand \\
\hline \multirow[b]{2}{*}{ Soil pH } & $\mathrm{pH}-\mathrm{H}_{2} \mathrm{O}$ & 5.6 & 5.5 & 5.2 \\
\hline & $\mathrm{pH}-\mathrm{KCl}$ & 5.1 & 5.2 & 5.0 \\
\hline Organic carbon ( $\%$ dry mass) & & 6.01 & 5.45 & 4.76 \\
\hline Organic matter ( $\%$ dry mass) & & 10.04 & 9.5 & 8.2 \\
\hline Total nitrogen $(\%)$ & & 0.52 & 0.47 & 0.42 \\
\hline $\mathrm{C} / \mathrm{N}$ ratio & & 11.56 & 11.57 & 12.87 \\
\hline \multirow{4}{*}{ Exchangeable bases (me/100g of soil) } & Calcium & 15.3 & 13.97 & 11.11 \\
\hline & Magnesium & 3.79 & 3.92 & 2.56 \\
\hline & Potassium & 1.7 & 1.71 & 1.34 \\
\hline & sodium & 0.01 & 0.01 & 0.01 \\
\hline Cation exchange capacity (me/100g of soil) at $\mathrm{pH} 7$ & & 28.8 & 27.81 & 24.17 \\
\hline Base saturation $(\%)$ & & 72.5 & 70.26 & 62.14 \\
\hline Available phosphorus (mg/kg) & & 66.6 & 70.51 & 67.08 \\
\hline $\mathrm{Ca} / \mathrm{Mg}$ & & 4.04 & 3.56 & 4.34 \\
\hline $\mathrm{Mg} / \mathrm{K}$ & & 2.23 & 2.39 & 1.91 \\
\hline $\mathrm{Ca} / \mathrm{Mg} / \mathrm{K}$ & & $74 / 18 / 8$ & $71 / 20 / 9$ & $74 / 17 / 9$ \\
\hline Exchangeable sodium percentage $(\%)$ & & 0.05 & 0.05 & 0.04 \\
\hline $\mathrm{N} / \mathrm{pH}-\mathrm{H}_{2} \mathrm{O}$ & & 0.93 & 0.85 & 0.81 \\
\hline Clay+ silt & & 29 & 36 & 33 \\
\hline
\end{tabular}

Table 2: Mean Separation of Plant Height, Leaf Surface Area and Number of Leaves with Respect to Variety

\begin{tabular}{llllll}
\hline $\begin{array}{l}\text { Growth } \\
\text { parameters }\end{array}$ & $\begin{array}{l}\text { Plant height }(\mathrm{cm}) \\
\text { Morgan }\end{array}$ & Cogito & $\begin{array}{l}\text { Number of leaves } \\
\text { Morgan }\end{array}$ & Cogito & $\begin{array}{l}\text { Leaf surface area }\left(\mathrm{cm}^{2}\right) \\
\text { Morgan }\end{array}$ \\
\hline Means & $26.50^{\mathrm{a}}$ & $39.26^{\mathrm{b}}$ & $33.26^{\mathrm{b}}$ & $22.11^{\mathrm{a}}$ & $18.21^{\mathrm{a}}$ \\
\hline
\end{tabular}

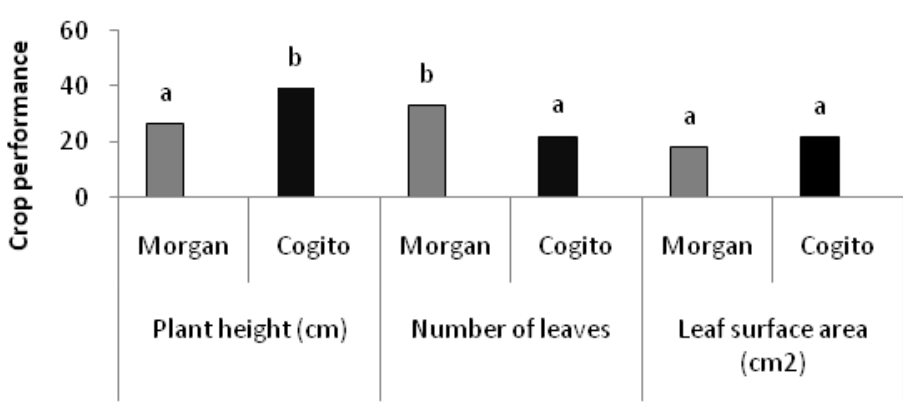

Growth parameters per variety

Fig. 3: Graphical plot of Plant Height, Leaf Surface Area and Number of Leaves with Respect to Variety.

\subsubsection{Effect of dolomite dose on growth parameters}

The mean separations of the plant height, leaf surface area and number of leaves linked to the variation of dolomite dose are shown in Table 3 and Fig. 3. Thus, dolomite dose did not have any significant effect $(\mathrm{P}>0.05)$ on all the growth parameters. Concerning the means of leaf surface area, the doses 1 tons ha- $\left(19.97 \mathrm{~cm}^{2}\right), 1.5$ tons ha- $\left(19.93 \mathrm{~cm}^{2}\right)$ and 2 tons ha- $\left(20.49 \mathrm{~cm}^{2}\right)$ recorded the highest values. The least scores were recorded by 0 tons $\mathrm{ha}^{-1}\left(19.68 \mathrm{~cm}^{2}\right)$ and 3 tons $\mathrm{ha}^{-1}\left(19.52 \mathrm{~cm}^{2}\right)$. 
Table 3: Mean Separation of Plant Height, Leaf Surface Area and Number of Leaves with Respect Dose of Dolomite.

\begin{tabular}{llll}
\hline Dolomite dose $\left(\right.$ tons ha $\left.{ }^{-1}\right)$ & Llant height $(\mathrm{cm})$ & Leaf surface area $\left(\mathrm{cm}^{2}\right)$ & $27.67^{\mathrm{a}}$ \\
\hline 0 & $32.72^{\mathrm{a}}$ & $19.68^{\mathrm{a}}$ & $27.17^{\mathrm{a}}$ \\
0.5 & $33.50^{\mathrm{a}}$ & $19.72^{\mathrm{a}}$ & $25.58^{\mathrm{a}}$ \\
1 & $32.25^{\mathrm{a}}$ & $19.97^{\mathrm{a}}$ & $26.92^{\mathrm{a}}$ \\
1.5 & $31.79^{\mathrm{a}}$ & $19.93^{\mathrm{a}}$ & $30.18^{\mathrm{a}}$ \\
2 & $34.76^{\mathrm{a}}$ & $20.49^{\mathrm{a}}$ & $29.96^{\mathrm{a}}$ \\
2.5 & $33.44^{\mathrm{a}}$ & $19.79^{\mathrm{a}}$ & $26.33^{\mathrm{a}}$ \\
3 & $32.00^{\mathrm{a}}$ & $19.52^{\mathrm{a}}$ & \\
\hline
\end{tabular}

\subsubsection{Effect of interaction of dolomite dose and crop variety on the growth parameters}

The mean separations of the plant height, leaf surface area and number of leaves related to the interaction of dolomite dose and variety are shown in Table 4. Thus, this interaction showed no significant difference $(\mathrm{P}>0.05)$ on all the growth parameters. Nevertheless, the highest means of plant heights were recorded in Morgan with the doses 0.5 tons ha $^{-1}(28.71 \mathrm{~cm})$ and 2 tons ha ${ }^{-1}(28.40 \mathrm{~cm})$, meanwhile the lowest means of were scored by the dose 1.5 tons ha-1 $(23.89 \mathrm{~cm})$. On the other hand, the highest means of plant heights recorded in Cogito corresponded to dolomite doses 2 tons ha-1 $(42.12 \mathrm{~cm})$ and 2.5 tons ha- $1(40.26 \mathrm{~cm})$, while the lowest mean values were recorded by the dolomite dose 3 tons ha-1 $(37.58 \mathrm{~cm})$.

Table 4: Mean Separation of Plant Height, Leaf Surface Area and Number of Leaves Linked to Dolomite Dose- Variety Interaction

\begin{tabular}{|c|c|c|c|c|c|c|}
\hline \multirow{2}{*}{ Dolomite dose (tons ha $\left.{ }^{-1}\right)$} & \multicolumn{2}{|c|}{ Plant height $(\mathrm{cm})$} & \multicolumn{2}{|c|}{ Number of leaves } & \multicolumn{2}{|c|}{ Leaf surface area $\left(\mathrm{cm}^{2}\right)$} \\
\hline & Morgan & Cogito & Morgan & Cogito & Morgan & Cogito \\
\hline 0 & $26.12^{\mathrm{a}}$ & $39.32^{\mathrm{a}}$ & $33.31^{\mathrm{a}}$ & $22.03^{\mathrm{a}}$ & $17.71^{\mathrm{a}}$ & $21.65^{\mathrm{a}}$ \\
\hline 0.5 & $28.71^{\mathrm{a}}$ & $38.29^{\mathrm{a}}$ & $33.17^{\mathrm{a}}$ & $21.17^{\mathrm{a}}$ & $18.46^{\mathrm{a}}$ & $20.98^{\mathrm{a}}$ \\
\hline 1 & $25.97^{\mathrm{a}}$ & $38.53^{\mathrm{a}}$ & $30.44^{\mathrm{a}}$ & $20.72^{\mathrm{a}}$ & $18.23^{\mathrm{a}}$ & $21.71^{\mathrm{a}}$ \\
\hline 1.5 & $23.89^{\mathrm{a}}$ & $39.67^{\mathrm{a}}$ & $31.69^{\mathrm{a}}$ & $22.14^{\mathrm{a}}$ & $18.34^{\mathrm{a}}$ & $21.53^{\mathrm{a}}$ \\
\hline 2 & $28.40^{\mathrm{a}}$ & $41.12^{\mathrm{a}}$ & $38.97^{\mathrm{a}}$ & $21.39^{\mathrm{a}}$ & $19.15^{\mathrm{a}}$ & $21.82^{\mathrm{a}}$ \\
\hline 2.5 & $26.62^{\mathrm{a}}$ & $40.26^{\mathrm{a}}$ & $36.11^{\mathrm{a}}$ & $23.81^{\mathrm{a}}$ & $17.94^{\mathrm{a}}$ & $21.65^{\mathrm{a}}$ \\
\hline 3 & $26.42^{\mathrm{a}}$ & $37.58^{\mathrm{a}}$ & $29.14^{\mathrm{a}}$ & $23.53^{\mathrm{a}}$ & $17.62^{\mathrm{a}}$ & $21.41^{\mathrm{a}}$ \\
\hline
\end{tabular}

As for the means of leaf surface areas, the dose 2 tons ha- ${ }^{-1}$ recorded the highest value $\left(19.15 \mathrm{~cm}^{2}\right)$ meanwhile the dose 0 tons ha ${ }^{-1}$ and 3 tons $\mathrm{ha}^{-1}$ revealed the lowest values $\left(17.71 \mathrm{~cm}^{2}\right.$ and $17.62 \mathrm{~cm}^{2}$, respectively) for variety 1 . For Morgan, the dose 2 tons ha' $\mathrm{recorded} \mathrm{the}^{-1}$ highest score $\left(21.82 \mathrm{~cm}^{2}\right)$ while the dose 0.5 tons $\mathrm{ha}^{-1}$ recorded the lowest value $\left(20.98 \mathrm{~cm}^{2}\right)$.

Concerning the means of number of leaves per plant, the highest scores were recorded by 2 tons ha ${ }^{-1}$ and 2.5 tons ha ${ }^{-1}$ ( 38.97 and 36.11 , respectively). The lowest values were scored by the doses 1 ton ha ${ }^{-1}$ and 3 ton ha ${ }^{-1}$ (30.44 and 29.14, respectively) as concerns Morgan. For Cogito, the lowest values are revealed by the doses 2.5 tons ha- ${ }^{-1}$ and 3 tons ha ${ }^{-1}$ ( 23.81 and 23.53, respectively). The dose 1 ton ha ${ }^{-1}$ produced the lowest number of leaves per plant (20.72).

\subsection{Effects of variety, dolomite dose and dolomite dose versus variety interaction on yield parameters}

\subsubsection{Effect of variety on yield parameters}

The mean separation of the length of extrafine pods (LPEx), number of extrafine pods (NPex), weight of extrafine pods (WPEx), number of pods exceeding caliber $\left(\mathrm{NPH}_{\mathrm{C}}\right)$ linked to variety are shown in Table 5. The factor variety had a very significant effect $(\mathrm{P}<0.001)$ on all the yield parameters. Cogito recorded the highest mean values of LGEx $(13.88 \mathrm{~cm})$, NGEx (40.94 pods per plant), WGEx (16.96 tons ha$\left.{ }^{1}\right)$ and NPHC (3.37 pods per plant) and WPHC (pods per plant). Morgan scored the lowest mean values for all the yield parameters: LGEx $(9.46 \mathrm{~cm})$, NGEx (24.09 pods per plant), WGEx (7.87 tons ha $\left.{ }^{-1}\right)$ and $\mathrm{NPH}_{\mathrm{C}}(1.2$ pods per plant) and WPHC $(0.65$ pods per plant).

Table 5: Mean Separation of Length of Extrafine Pods, Number of Extrafine Pods, Weight of Extrafine Pods, Number of Pods Exceeding Caliber and of Pods Exceeding Caliber with Respect to Variety

\begin{tabular}{lllllllllll}
\hline Growth & LPEx & & NPEx & & WPEx & & $\mathrm{NPH}_{\mathrm{C}}$ & & $\mathrm{WPH}_{\mathrm{C}}$ & \\
Parameters & Morgan & Cogito & Morgan & Cogito & Morgan & Cogito & Morgan & Cogito & Morgan & Cogito \\
\hline Means & $9.46^{\mathrm{a}}$ & $13.88^{\mathrm{b}}$ & $24.09^{\mathrm{a}}$ & $40.94^{\mathrm{b}}$ & $7.87^{\mathrm{a}}$ & $16.96^{\mathrm{b}}$ & $1.21^{\mathrm{a}}$ & $3.37^{\mathrm{b}}$ & $0.65^{\mathrm{a}}$ & $2.46^{\mathrm{b}}$ \\
\hline
\end{tabular}

LPEx: Length of extrafine pods; NPEx: number of extrafine pods; WPEx: weight of extrafine pods; NPHc: number of pods exceeding caliber; WPHC: weight of pods exceeding caliber; Var: variety

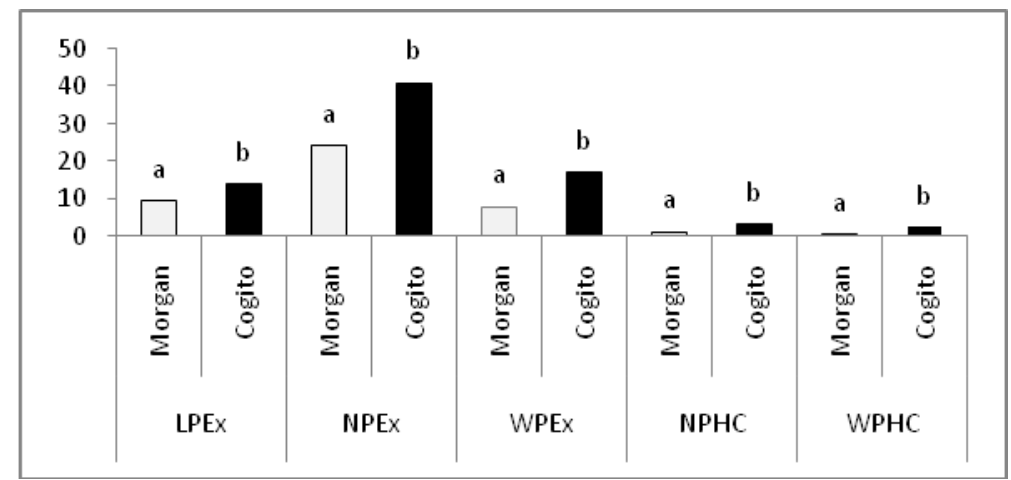

Fig. 4: Mean Values of Length of Extrafine Pods, Number of Extrafine Pods, Weight of Extrafine Pods, Number of Pods Exceeding Caliber and of Pods Exceeding Caliber with Respect to Variety. 


\subsubsection{Effect of dolomite dose on yield parameters}

The mean separations of yield parameters (LPEx, NPEx, WPEx, NPHC and $\mathrm{WPH}_{\mathrm{C}}$ ) with respect to dolomite dose are presented in Table 6 and Fig. 4. Thus, apart from WPEx, the factor dolomite dose did not show any significant effect $(\mathrm{P}>0.05)$ on the rest of the yield parameters. However, the highest mean of LPEx $(14.24 \mathrm{~cm})$ was recorded by the dose 0.5 tons ha ${ }^{-1}$ and the lowest mean $(11.26 \mathrm{~cm})$ was obtained from the dose 3 tons ha ${ }^{-1}$. The lowest values of NPEx were recorded with dose of 2 tons ha ${ }^{-1}$ ( 44.16 pods per plant) and 2.5 tons $\mathrm{ha}^{-1}$ ( 34.83 pods per plant) while the lowest mean was scored by the dose 1 ton ha ${ }^{-1}$ (22.79 pods per plant). For $\mathrm{NPH}_{\mathrm{C}}$ and $\mathrm{WPH}$, the dose of 2 tons ha- 1 gave the highest values, that is, 2.84 pods per plant for a yield of 1.85 tons ha-1. The dose 1.5 tons ha' ${ }^{-1}$, on the other hand, scored the lowest mean values of $\mathrm{NPH}_{\mathrm{C}}$ (1.94 pods per plant) and $\mathrm{WPH}_{\mathrm{C}}$ (1.32 pods per plant).

\begin{tabular}{|c|c|c|c|c|c|}
\hline & LPEx $(\mathrm{cm})$ & NPEx & WPEx(tons ha-1) & $\mathrm{NPH}_{\mathrm{C}}$ & $\mathrm{WPH}_{\mathrm{C}}$ (tons ha-1) \\
\hline 0 & $11.81^{\mathrm{a}}$ & $32.94^{\mathrm{a}}$ & $12.91^{\mathrm{a}}$ & $2.51^{\mathrm{a}}$ & $1.76^{\mathrm{a}}$ \\
\hline 0.5 & $14.24^{\mathrm{a}}$ & $30.95^{\mathrm{a}}$ & $11.96^{\mathrm{ab}}$ & $2.05^{\mathrm{a}}$ & $1.44^{\mathrm{a}}$ \\
\hline 1 & $11.63^{\mathrm{a}}$ & $27.79^{\mathrm{a}}$ & $10.63^{\mathrm{a}}$ & $2.07^{\mathrm{a}}$ & $1.47^{\mathrm{a}}$ \\
\hline 1.5 & $11.78^{\mathrm{a}}$ & $33.32^{\mathrm{a}}$ & $12.25^{\mathrm{abc}}$ & $1.94^{\mathrm{a}}$ & $1.32^{\mathrm{a}}$ \\
\hline 2 & $12.24^{\mathrm{a}}$ & $34.16^{\mathrm{a}}$ & $12.84^{\mathrm{bc}}$ & $2.84^{\mathrm{a}}$ & $1.85^{\mathrm{a}}$ \\
\hline 2.5 & $11.70^{\mathrm{a}}$ & $34.83^{\mathrm{a}}$ & $13.61^{\mathrm{c}}$ & $2.52^{\mathrm{a}}$ & $1.69^{\mathrm{a}}$ \\
\hline 3 & $12.26^{\mathrm{a}}$ & $33.62^{\mathrm{a}}$ & $12.89^{\mathrm{bc}}$ & $2.08^{\mathrm{a}}$ & $1.38^{\mathrm{a}}$ \\
\hline
\end{tabular}

The WGEx showed a significant effect $(\mathrm{P}<0.05)$ on the dolomite dose. The highest mean value was scored with 2 tons ha $^{-1}$ dose $(13.61$ tons ha $\mathrm{h}^{-1}$ of extrafine pods) while the lowest mean value was obtained with 1 tons ha ${ }^{-1}$ (10.63 tons ha ${ }^{-1}$ of extrafine pods). Nevertheless, there was no significant effect between the values of the doses 2.5 tons $\mathrm{ha}^{-1}$ and 0 tons ha ${ }^{-1}$.

\subsubsection{Mean separation of yield parameters with respect to dolomite dose versus crop variety interaction}

The mean separations of the yield parameters (LPEx, NPEx, WPEx, $\mathrm{NPH}_{\mathrm{C}}$ and $\mathrm{WPH}_{\mathrm{C}}$ ) with respect to dolomite dose versus variety interaction are shown in Table 7. Thus, the dolomite dose-variety interaction did not have any significant effect $(\mathrm{P}>0.05)$ on all the yield parameters. Nevertheless, the highest mean values of LPEx in Morgan were recorded with 2 tons ha- $(9.96 \mathrm{~cm})$ and 0 tons ha-1 $(9.84$ $\mathrm{cm})$, while the lowest ones were scored by 3 tons ha- $1(8.59 \mathrm{~cm})$. On the other hand, the highest mean values of LPEx in Cogito were observed for dose 3 tons ha- 1 while the lowest ones appeared for 0.5 tons ha-1 $(13.7 \mathrm{~cm})$.For NPEx of Morgan, the highest means were recorded for 2 tons $\mathrm{ha}^{-1}$ (27.27 pods per plant) while the lowest ones were scored by 1 tons ha $\mathrm{h}^{-1}$ (19.38 pods per plant). For Cogito, the doses 2.5 tons ha ${ }^{-1}$ and 3 tons ha ${ }^{-1}$ recorded the highest values (43.69 and 44.72 pods, respectively) meanwhile dose 1 tons ha ${ }^{-1}$ registered the lowest mean of NPEx (36.19 pods).

The highest mean values of WPEx for Morgan were scored by doses 0 ton $\mathrm{ha}^{-1}\left(8.7\right.$ tons ha $\left.^{-1}\right)$ and 2.5 tons ha ${ }^{-1}\left(8.72\right.$ tons ha- $\left.{ }^{-1}\right)$. The lowest mean values were recorded by the 1 ton $\mathrm{ha}^{-1}\left(6.72\right.$ tons ha $\left.^{-1}\right)$ and 2 tons ha $\mathrm{h}^{-1}\left(6.67\right.$ tons ha $\left.\mathrm{h}^{-1}\right)$. For Cogito, the highest mean values were recorded for the doses 2.5 tons ha ${ }^{-1}\left(18.5\right.$ tons $\left.\mathrm{ha}^{-1}\right)$ and 3 tons ha ${ }^{-1}\left(18.38\right.$ tons ha $\left.{ }^{-1}\right)$. The lowest WPEx value was scored by the dose 1 ton ha ${ }^{-1}\left(14.56\right.$ tons $\left.h^{-1}\right)$.

Table 7: Mean Separation of Yield Parameters (Lpex, Npex, Wpex, $\mathrm{NPH}_{\mathrm{C}}$ and $\mathrm{WPH}_{\mathrm{C}}$ ) with Respect to Dolomite Dose versus Crop Variety Interaction

\begin{tabular}{|c|c|c|c|c|c|c|c|c|c|c|}
\hline \multirow{2}{*}{$\begin{array}{l}\text { Dolomite } \\
\text { dose }\end{array}$} & \multicolumn{2}{|c|}{ LPEx (cm) } & \multicolumn{2}{|l|}{ NPEx } & \multicolumn{2}{|c|}{ WPEx(tons ha $\left.{ }^{-1}\right)$} & \multicolumn{2}{|l|}{$\mathrm{NPH}_{\mathrm{C}}$} & \multicolumn{2}{|c|}{$\mathrm{WPH}_{\mathrm{C}}$ (tons ha ${ }^{-1}$ ) } \\
\hline & Morgan & Cogito & Morgan & Cogito & Morgan & Cogito & Morgan & Cogito & Morgan & Cogito \\
\hline 0 & $9.84^{\mathrm{a}}$ & $13.78^{\mathrm{a}}$ & $24.78^{\mathrm{a}}$ & $41.11^{\mathrm{a}}$ & $8.70^{\mathrm{a}}$ & $17.12 \mathrm{a}$ & $1.14 \mathrm{a}$ & $3.89 \mathrm{a}$ & $0.62 a$ & $2.90 \mathrm{a}$ \\
\hline 0.5 & $8.92^{\mathrm{a}}$ & $13.57^{\mathrm{a}}$ & $22.88^{\mathrm{a}}$ & $39.02^{\mathrm{a}}$ & $7.20^{\mathrm{a}}$ & $16.32 \mathrm{a}$ & $1.00 \mathrm{a}$ & $3.11 \mathrm{a}$ & $0.52 \mathrm{a}$ & $2.36 \mathrm{a}$ \\
\hline 1 & $9.59^{\mathrm{a}}$ & $13.66^{\mathrm{a}}$ & $19.38^{\mathrm{a}}$ & $36.19^{\mathrm{a}}$ & $6.71^{\mathrm{a}}$ & $14.56 \mathrm{a}$ & $1.05 \mathrm{a}$ & $3.08 \mathrm{a}$ & $0.60 \mathrm{a}$ & $2.35 \mathrm{a}$ \\
\hline 1.5 & $9.77^{\mathrm{a}}$ & $13.80^{\mathrm{a}}$ & $25.83^{\mathrm{a}}$ & $40.80^{\mathrm{a}}$ & $7.67^{\mathrm{a}}$ & $16.83 \mathrm{a}$ & $1.14 \mathrm{a}$ & $2.75 a$ & $0.62 \mathrm{a}$ & 2.02 \\
\hline 2 & $9.96^{\mathrm{a}}$ & $14.52^{\mathrm{a}}$ & $27.27^{\mathrm{a}}$ & $41.05^{\mathrm{a}}$ & $6.67^{\mathrm{a}}$ & $17.02 \mathrm{a}$ & $1.49 \mathrm{a}$ & $4.19 a$ & $0.81 \mathrm{a}$ & $2.89 \mathrm{a}$ \\
\hline 2.5 & $9.53^{\mathrm{a}}$ & $13.87^{\mathrm{a}}$ & $25.97^{\mathrm{a}}$ & $43.69^{\mathrm{a}}$ & $8.71^{\mathrm{a}}$ & $18.50 \mathrm{a}$ & $1.39 \mathrm{a}$ & $3.66 \mathrm{a}$ & $0.71 \mathrm{a}$ & $2.68 \mathrm{a}$ \\
\hline 3 & $8.59^{\mathrm{a}}$ & $8.59^{\mathrm{a}}$ & $22.53^{\mathrm{a}}$ & $44.72^{\mathrm{a}}$ & $7.41 \mathrm{a}$ & $18.38 \mathrm{a}$ & $1.27 \mathrm{a}$ & $2.89 \mathrm{a}$ & $0.70 \mathrm{a}$ & $2.06 \mathrm{a}$ \\
\hline
\end{tabular}

The highest mean values of $\mathrm{NPH}_{\mathrm{C}}$ for Morgan were shown by 2 tons ha ${ }^{-1}$ (1.49 pods per plant) while 0.5 tons ha $\mathrm{h}^{-1}$ and 1 tons ha- $\mathrm{scored}^{-1}$ the least values (3.89 and 4.19 pods per plant, respectively). For Cogito, the doses 0 tons ha ${ }^{-1}$ and 2 tons ha ${ }^{-1}$ showed the highest NPHC mean values ( 2.90 tons $\mathrm{ha}^{-1}$ and 2.93 tons ha $\mathrm{a}^{-1}$, respectively) while the doses 0.5 tons $\mathrm{ha}^{-1}$ and 1 ton ha ${ }^{-1}$ scored the lowest NPHC mean values (3.11 and 3.08 pods, respectively).

The highest WPHC mean values for Morgan were produced by 2 tons ha $\mathrm{ha}^{-1}\left(0.81\right.$ tons ha $\left.\mathrm{h}^{-1}\right)$ while the lowest values was observed for dose 0.5 tons ha ${ }^{-1}\left(0.52\right.$ tons ha $\left.{ }^{-1}\right)$. For variety 2 , the highest WPHc mean values were observed for the doses 0 ton ha $\mathrm{h}^{-1}\left(2.9\right.$ tons ha $\left.^{-1}\right)$ and $^{2}$ tons ha ${ }^{-1}\left(2.89\right.$ tons ha $\left.{ }^{-1}\right)$. The lowest WPHc means were recorded for 1.5 tons ha ${ }^{-1}\left(2.02\right.$ tons ha $\left.^{-1}\right)$ and 2.06 tons ha ${ }^{-1}\left(2.06\right.$ tons ha $\left.^{-1}\right)$.

\section{Discussions}

\subsection{Nature of the studied Andosols}

Naturally, the Andosols in the studied plot showed a silty sandy texture at the surface (0-30 cm depth). The pH- $\mathrm{H}_{2} \mathrm{O}$ was highly to moderately acidic (5.2-5.6), below the favourable range (pH 6-6.5) for the optimum growth and development of green beans (Beernaert and Bitondo 1991). The organic matter content was very high and was of good quality $(\mathrm{C} / \mathrm{N}=11-13)$. The potential acidity was low $(\Delta \mathrm{pH}<0.5)$ portraying a low exchangeable acidity content. The exchangeable calcium and exchangeable $\mathrm{Mg}$ were high, exchangeable $\mathrm{K}$ was very high and the exchangeable Na was very low (Beernaert and Bitondo 1991). Also, the sum of exchangeable bases and available phosphorus were very high, while the cation exchange capacity and the base saturation were high. The fertility level of the studied soils was globally high according to Beernaert and Bitondo 1991). The works of Martin (1979) permit to understand that despite the intrinsic chemical fertility of PROLEG SA soils, other factors like topography, soil depth and the percentage of fine grains in the soil strongly influenced their global fertility. The $\mathrm{Ca} / \mathrm{Mg}$ ratios (3.56 and 3.34) fell within the zone of moderately high equilibrium in those soils (Beernaert and Bitondo, 1991), thus very favourable for plant uptake. $\mathrm{Mg} / \mathrm{K}$ ratios (1.91 and 2.39) fell between a low to optimum cationic equilibrium, which defines marginally suitability level for plant uptake. The $\mathrm{Ca} / \mathrm{Mg} / \mathrm{K}$ ratio shows that $\mathrm{Mg}$ and $\mathrm{K}$ were favourable 
meanwhile $\mathrm{Ca}$ was deficient in all the blocks with respect to the ideal equilibrium condition of $76 \% \mathrm{Ca}, 18 \% \mathrm{Mg}$ and $6 \% \mathrm{~K}$ (Martin 1979). The evaluation of exchangeable $\mathrm{K}$ revealed that it is above the $0.12 \mathrm{me} / 100 \mathrm{~g}$ absolute minimal level and is $8 \%$ of Sum of exchangeable bases ( $>2 \%$ critical limit).

\subsection{Implication of dolomite amendment on the yield and growth of green beans}

Green beans (Phaseolus vulgaris) are warm season crops which dislike hot conditions (Champa et al. 2008). The optimum temperature growth range is 15 to $27^{\circ} \mathrm{C}$. At lower temperatures, beans run a risk of poor quality, with short, puffy, malformed pods. Temperatures above $35^{\circ} \mathrm{C}$, especially when accompanied by hot, dry winds, may cause excessive shedding of flowers and young pods, resulting in poor yields. Ideal temperatures for germination are $20^{\circ} \mathrm{C}$ to $30^{\circ} \mathrm{C}$, when the plants should emerge within 5 to 10 days; the minimum temperature for germination is $10^{\circ} \mathrm{C}$. Beans are planted 4 to $7 \mathrm{~cm}$ apart in rows drawn 45 to $60 \mathrm{~cm}$ apart, but closer spacing is generally preferred. Seeds are planted directly in the field, to a depth of 3 to $5 \mathrm{~cm}$ in sandy soils, and 2 to $3 \mathrm{~cm}$ in heavy clay soils.

The present work aimed to assess the effect of seven dolomite doses on the growth and yield of two varieties of green beans. It appears that the variety Morgan recorded the highest mean plant height, lowest mean leaf surface area and highest mean number of leaves. These results agree with those of Tekeu (2013) showing a significant difference between maize varieties for germination rate, prolificacy and the aspect of the comb. Also, Thé et al. (2006) earlier reported a highly significant difference $(\mathrm{P}<0.001)$ between two maize cultivars under acid soils with the tolerant variety offering the best performance. The highly significant difference $(\mathrm{P}<0.001)$ observed in all the growth parameters could be related to the genotype of the two green beans varieties. In effect, Cogito with the best expression of growth parameters is a Dutch hybrid meanwhile Morgan is a home-based variety.

On the other hand, dolomite dose did not have any significant effect $(\mathrm{P}>0.05)$ on all the growth parameters. Concerning the means of leaf surface area, the doses 1 ton $\mathrm{ha}^{-1}, 1.5$ tons ha ${ }^{-1}$ and 2 tons ha ${ }^{-1}$ recorded the highest values while lowest scores were recorded by 0 ton ha ${ }^{-1}$ and 3 tons ha $^{-1}$. These results are similar to those already documented by Richirumuhirwa (1989) and Wafo (2006) whereby dolomite showed no significant difference neither on plant height nor number of leaves nor the length of corn comb. According to Boucherie et al. (2006), the choice of soil amendments depends on its rapid action measured in terms of carbonate solubility and the fineness of the particle size. This might be due to the fact that dolomite is a raw product which has a slow action. It has more coarse grains and dissolves very slowly. Thus, it might not have had the sufficient time to dissolve and produce the desired effects combined too with the fact that the growth cycle of beans is short.

The plant height, leaf surface area and number of leaves associated to the interaction of dolomite dose-variety showed no significant difference ( $>>0.05)$ on all the growth parameters. These results agree with those of Richirumuhirwa (1989) and Wafo (2006) on maize whereby dolomite showed no significant influence on plant height, number of leaves and the length of the comb. The effects of genotype and environmental factors have been highlighted by Foucteau et al. (2001) to represent 11 to $39 \%$ of the general effect on yield. A close look at the different growth parameters revealed that variety contributed higher effect compared to dolomite doses for each of the considered parameters but the interaction of the two factors did not have any significant effect. This could mean that dolomite did not have enough time to react in view of its low solubility and slow action (Soltner 1988). Also, green beans have a short growth cycle compared to the solubility rate of dolomite.

Cogito recorded the highest mean values of LGEx, NGEx, WGEx and NPHC and WPHC while Morgan scored the lowest mean values for all the yield parameters. These findings agree with Tekeu (2013) who observed significant differences between the genotypes of corn derived from comb aspect and grain yield. This might imply that under acid soil conditions, crop genotypes develop different mechanisms of tolerance within specific environments. The highly significant difference shown by variety for the different yield parameters might be because Cogito, that expressed the best potentials, is an improved Dutch variety meanwhile Morgan is a local Cameroonian variety. These findings, nevertheless, gainsay the results of Miranda and Rowell (1987), Kasongo et al. (2013) and Osondwa et al. (2013) who observed a significant effect on the performance of biomass and the yield of maize, soybeans and wheat. They worked on strongly leached acid $(\mathrm{pH}<5)$ soils and noted that dolomite significantly increased soil $\mathrm{pH}$, available $\mathrm{P}, \mathrm{CEC}$, exchangeable $\mathrm{Ca}^{2+}$ and $\mathrm{Mg}^{2+}$ and reduced exchangeable $\mathrm{Al}^{3+}$ and $\mathrm{H}^{+}$. However, Richirumuhirwa (1989) and Wafo (2006) reported no significant difference on the performance of beans, maize and cassava with respected to the control acid soil. The insignificant effect of dolomite used in the present study in Foumbot could be related to its intrinsic nature: raw, coarse, low solubility and slow reaction rate (Boucherie 2006) and the short cycle of green beans. Andosols are renowned for a high $\mathrm{pH}(>5.5)$, high saturation rate $(>50 \%)$ and low buffer capacity (Siéwé et al. 2008; Tsozué et al. 2015, 2016). Thus, Bekele et al. (2018) proposed the integrated use of lime with organic and chemical fertilizers as a good approach for sustainable crop production under acidic soils by building ecologically sound and economically viable farming systems. Tilahun et al. (2013) confirmed that neither inorganic nor organic fertilizers can singly sustain crop productivity.

The dolomite dose showed a significant effect $(\mathrm{P}<0.05)$ on the WGEx, and the highest mean value was scored with 2 tons ha-1 dose while the lowest mean value was obtained with 1 tons ha-1, in agreement with Miranda and Rowell (1987), Kasongo et al. (2013) and Osondwa et al. (2013). Nevertheless, insignificant effect observed between the means of WGEx for doses 2.5 tons ha $^{-1}$ and 0 ton ha ${ }^{-1}$ could be related to the residual effect of dolomite. In effect, the experimental plot has been previously amended with dolomite at $600 \mathrm{~kg}$ $\mathrm{ha}^{-1}$ two years ago. According to Osunndwa et al. (2013), amended soils are enriched with nutrients (Ca, Mg, N and P) susceptible of producing long term beneficial effects. Thus, the dolomite dose versus variety interaction did not show any significant effect $(\mathrm{P}>0.05)$ on all the yield parameters. The highest mean values of LPEx in Morgan were recorded with the dose 2 tons ha ${ }^{-1}$ and 0 ton ha ${ }^{-1}$, while the lowest ones were scored by 3 tons $\mathrm{ha}^{-1}$. On the other hand, the highest mean values of LPEx in Cogito were observed for 3 tons ha ${ }^{-1}$ while the lowest ones appeared for 0.5 tons ha ${ }^{-1}$. The et al. (2006) reported that the application of lime significantly influences the performance of two maize cultivars and $\mathrm{pH}$, increase in $\mathrm{Ca}$ and $\mathrm{Mg}$ and a reduction of exchangeable $\mathrm{Al}^{3+}$ and $\mathrm{H}^{+}$. In effect, the application of 2 tons ha $^{-1}$ of dolomite increased the grain yield of acid soils tolerant variety (ATP-SR-Y) by $82 \%$ and the vulnerable variety (Tuxpeňasequia ) by $208 \%$, followed in the soil by a $43 \%$ reduction exchangeable $\mathrm{Al}^{3+}$ and $51 \%$ of exchangeable $\mathrm{H}^{+}$, an increment in $\mathrm{pH}$ (0.27 units), CEC (5\%), exchangeable $\mathrm{Ca}(154 \%)$ and $\mathrm{Mg}(481 \%)$. Foucteau et al.(2001) already observed a better performance of crop variety on growth and yield compared to dolomite doses but attributed significant effects of interaction of the two factors to the fact that the dolomite did not have enough time to react considering it low solubility and its slow action.

\section{Conclusions}

The aim of the present work was to assess the effect of different doses of dolomite powder on the growth and yield of two green beans varieties (Morgan and Cogito). The experiment was conducted on the experimental farm of PROLEG, SA in Foumbot on an Andosol. 
The main results revealed that the growth and yield parameters showed highly significant differences $(\mathrm{P}<0.001)$ in the two varieties. The Cogito variety produced the longest $(13.88 \mathrm{~cm})$, most numerous (40.94 pods per plant) and highest (16.96 tons ha- 1$)$ extrafine pods. The different doses as a whole did not produce significant effects $(\mathrm{P}>0.05)$ except for the weight of extrafine pods. The highest yield was 13.61 tons ha- 1 for extrafine pods obtained from 2 tons ha- 1 dolomite dose. The interaction between the two factors did not produce any significant difference $(\mathrm{P}>0.05)$ on all the studied parameters. There is need for farmers to improve soil quality with compost and cover crops to check nutrient leaching and erosion.

\section{Acknowledgements}

Special thanks go to the staff of PROLEG SA Foumbot (Cameroon) for their assistance in terms of facilities and advise during the experimentation.

\section{Conflict of interests}

The authors declare no conflict of interests

\section{References}

[1] Allen DJ, Brent GF (2010) Sequestering $\mathrm{co}_{2}$ by mineral carbonation: stability against acid rain exposure. Environmental science and technology, 44, 2735-2739, https://doi.org/10.1021/es903212j

Ambassa-kiki R, Yemefack M, Tchienkoua (2002) Caracteristique biophysique et aptitude a la production végétale, animale et piscicole. (IRAD, Yaoundé).

[3] Anon (2003) Beans. In: Vegetable Cultivation. (Ed Mankotte KN). (Department of Agriculture: Peradeniya).

[4] Azinwi Tamfuh P, Tsozué D, Tita MA, Boukong A, Ngnipa Tchinda R, Ntangmo Tsafack H, Mvondo Ze AD (2017) Effect of Topographic Position and Seasons on the Micronutrient Levels in Soils and Grown Huckleberry (Solanum scabrum) in Bafut (North-West Cameroon). World Journal of Agricultural Research 5(2), 73-87. doi: 10.12691/wjar-5-2-3. https://doi.org/10.12691/wjar-5-2-3.

[5] Azinwi Tamfuh P, Temgoua E, wotchoko P, Boukong A, Bitom D (2018) Soil properties and land capability evaluation in a mountainous ecosystem of North-West Cameroon. Journal Of Geoscience and Environment Protection, 6, 15-33. https://doi.org/10.4236/gep.2018.67002

[6] Beernaert F, Bitondo D (1991) Land evaluation. (University Centre of Dschang: Dschang).

[7] Beernaert F, Bitondo D (1992) 'Simple and practical methods to evaluate analytical data of soil profiles'. (University Centre of Dschang: Dschang).

[8] Bekele A, Kibret K, Bedadi B, Balemi T and Yli-Halla M (2018) Effects of lime, vermicompost and chemical P fertilizer on yield of maize in Ebantu District, Western highlands of Ethiopia. African Journal of Agricultural Research 13(10), 477-489. https://doi.org/10.5897/AJAR2017.12949

[9] Bindzi TJ (1987) Les sol rouges du Cameroun.(MESIRES-FAO :Yaoundé).

[10] Borrero JC, Pandey S, Ceballos H, Magnavaca R, Bahia AFC (1995) Genetic variances for tolerance to soil acidity in a tropical maize population. Maydica 40, 283-8.

[11] Boucherie R., Hopquin B., Kouassi S., Delliou B., Nivet L., 2006. Guide de fertilisation. Unilet. Inf, nº spécial.

[12] Brady NC, Weil RR (2014) The Nature and properties of soils'. 14 $4^{\text {th }}$ edn (Prentice Hall: New York).

[13] Bremner JM, Mulvaney CS (1982) Total Nitrogen. In: Methods of soil analysis. pp. 595-624 (Ed Buxton DR, ed) Part 2. (American Society of Agronomy Inc. and Soil Science Society of America Inc: Madison).

[14] Champa WAH, Weerakkody WAP, Palipane KB (2008) Maturity indices for harvesting of beans (Phaseolous vulgaris L.), variety KWG in dry zone cultivations in Sri Lanka. Tropical Agricultural Research 20, 123 - 133.

[15] Duchaufour P (1997). Handbook of Pedology: soil- vegetation-environment. (Masson: Paris).

[16] FAO (2006) Guidelines for Soil Description, a Framework for International Classification, Correlation and Communication. $4^{\text {th }}$ Ed, (Food and Agricultural Organization of the United Nations: Rome).

[17] FAO-ISRIC (2006) World Reference Base for soilresources. (FAO: Rome).

[18] Getachew E, Mohammed A, Tesfaye A, Nebiyu A (2014) Growth and yield response of green beans (Phaseolus vulgaris L.) in relation to time of sowing and plant spacing in the humid tropics of Jimma, southwest Ethiopia. International Journal of Soil and Crop Sciences 2(7), 22-23.

[19] Foucteau V, El Daouk M, Baril C (2001) Interpretation of genotype by environment interaction in twosunflower networks. Theoretical and Applied Genetics 102, 327-334.https://doi.org/10.1007/s001220051649.

[20] Getachew E, Mohammed A, Tesfaye A, Nebiyu A (2014) Growth and yield response of green beans (Phaseolus vulgaris L.) in relation to time of sowing and plant spacing in the humid tropics of Jimma, southwest Ethiopia.International Journal of Soil and Crop Sciences 2(7), 22-23.

[21] Ibrahim M, Han K, Ha S, Zhang Y, Hur S (2012) Physico-chemical characteristics of disturbed soils affected by accumulate of different textures in South Korea. Sains Malays 4(3), 285-291.

[22] Jos R, Kathirvelan P, Kalasiselvan P (2007) Groundnut (Arachis hypogea L.) Leaf area estimation using allometric model. Research Journal of Agricultural and Biolological Science 3, 59-61.

[23] Kaho F, Yemefack M, Yongue-Fouateu R, Kanmegne J, Bilong P (2007) Potentials of Calliandracalothyrsus Meissner for improving soil fertility and crop performance in the Forest Savannah-Transition Zone of Cameroon. Nigerian Journal of Soil and Environmental Research 7 , 33-44p.https://doi.org/10.4314/njser.v7i1.28416

[24] Kamga TR, Kouamé C, Atangana AR, Chagomoka T, Ndango R (2013) Nutritional evaluation of five African indigenous vegetables. Journal of Horticultural Research 21(1), 99-106.https://doi.org/10.2478/johr-2013-0014

[25] Kasongo LME, Mwamba MT, Tshipoya MP, Mukalay MJ, Useni SY, Mazinga KM, Nyembo KL (2013) Response of soybean (Glycine max L. (Merril) to the green biomass of Tithoniadiversifolia (Hemsley) A. Gray used as organic fertilizer on a Ferralsol in Lubumbashi, DR Congo. Journal of Applied Biosciences 63, 4727 - 4735https://doi.org/10.4314/jab.v63i1.87247

[26] Letouzey R (1985) Notice de la Carte Phytogeographique du Cameroun au 1/500000. (Institut de la Carte de Végétation: Toulouse).

[27] Martin, D (1979) Chemical Fertility of Soils in a Ranch in Congo. Cah ORSTOM, Série Pédologie, 17, 47-64.

[28] Miranda LHD, Rowell DL (1987). The effects of lime and phosphorus on the function of wheat roots in acid tropical soils and subsoils. Plant and Soil, 104, 253-262.https://doi.org/10.1007/BF02372539. 
[29] Muñoz-Sanchez AJ, Domínguez-Domínguez ER, Hernández-Sotomayor TSM (2015) Characterizing the relationship between aluminum content and $\mathrm{pH}$ in coffee (Coffea arabica L.) crop soils in Mexico. International Journal of Agriculture and Crop Sciences 8 (1), 39-46.

[30] Ngandeu Mboyo JD, Yongue-Fouateu R, Yemefack M, Bilong P (2008) Variabilité spatiale de la productivité d'un Andosol Leptique de la région de Foumbot, Ouest Cameroun. Etude et Gestion des Sols 15 (2), 87-96

[31] Olsen SR, Sommers LE (1980) Phosphorus. In: Methods of Soil Analysis (Eds Page AL, Buxto, RH, Miller Keeney DR) pp.403-430. (American society of Agronomy: Madison).

[32] Opala PA, Kisinyo PO, Nyambati RO (2015) Effects of farmyard manure, urea and phosphate fertilizer application methods on maize yields in western Kenya. Journal of Agricultural and Rural Development in the Tropics Subtropics 116(1), 1-9.

[33] Osundwa MA, Okalebo JR, Ngetich WK, Ochuodho JO, Othieno CO, Langat B, Omenyo VS (2013). Influence of Agricultural Lime on Soil Properties and Wheat (Triticum aestivum L.) Yield on Acidic Soils of Uasin Gishu County, Kenya. American Journal of Experimental Agriculture 3(4), 806-823.https://doi.org/10.9734/AJEA/2013/3446.

[34] Rhoades JD (1982) Cation exchanges capacity. In: Methods of soil analysis (Eds Page AL, Buxton RH, Miller Keeney DR) pp.149-158. (American society of Agronomy, Madison: USA).

[35] Rishirumuhirwa T, Roose E (1989) Effects of organic and mineral matters on mountain acid soils remediation in Burundi. Scientific registration no.1498, Symposium 38.

[36] Sama A (1989) Acidification des sols sous culture. Valorisation de la Dolomie de Tiara. Mémoire d'Ingénieur du Développement Rural, IDRIVO.

[37] Siéwé JM, DjoufacWoumfo E, Bitom D, Figueras F, Djomgoué P, Njopwouo D and AzinwiTamfuh P (2008). Andosols of the Bambouto Mountains (West Cameroon): Characteristics, Superficial Properties - Study of the Phosphate Ions Adsorption. The Open Inorganic Chemistry Journal, , 2, 106-115 Tsozué D, Tematio P, AzinwiTamfuh P (2016) https://doi.org/10.2174/1874098700802010106.

[38] Soltner D (1988). Les grandes productions végétales. Les collections sciences et techniques agricoles, Ed. 16éme éditions 464P.

[39] Tabi FO, Omoko M, Boukong A, Mvondo Ze AD, Bitondo D, Fuh-Che C (2012) Evaluation of Lowland rice (Oryza sativa) production system and management recommendations for Logone and Chari flood plain-Republic of Cameroon. Agricultural Science Research Journal 2(5), 261273.

[40] Teir S, Eloneva S, Fogelholm CJ, Zevenhoven R (2006) Stability of calcium carbonate and magnesium carbonate in rainwater and nitric acid solutions. Energy Conversion and Management, 47, 3059-3068. https://doi.org/10.1016/i.enconman.2006.03.021.

[41] Thé C, Calba H, Horst WJ, Zonkeng C (2001) Three years performance of a tolerant and a susceptible maize cultivar on non-amended and amended acid soil. In 'Plant nutrition: Food security and sustainability of agro-ecosystems through basic and applied research'(Eds Horst Walter J, Schenk MK, Bürkert A, Claasen N, Flessa H, Frommer WB et al pp. 984-985 Academic Publishers: Hanovre.https://doi.org/10.1007/0306-47624-X 479.

[42] Thomas GW (1982) Exchangeable Cations. In: Methods of Soil Analysis. (Eds Page AL, Buxton RH, Miller Keeney DR) pp.159-165. (American society of Agronomy: Madison).

[43] Tekeu H (2013) Evaluation des hybrides de maïs (Zeamays L.) pour la tolérance aux sols acides à toxicité alumique et manganique en zones forestières humides. Mémoire de Master en Biotechnologies Végétales. Université de Yaoundé I, Yaoundé.

[44] Thé C, Calba H, Zonkeng C, Ngonkeu ELM, Adetimirin VO, Mafouasson HA, Meka SS, Horst WL (2006) Response of maize grain yield to changes in acid characteristics after soil amendments. Plant and Soil 284, 45-57.https://doi.org/10.1007/s11104-006-0029-9.

[45] Tilahun T, Nigussie D, Wondimu B, Setegn G (2013) Effect of farmyard manure and inorganic fertilizers on the growth, yield and moisture stress tolerance of rain-fed lowland rice. American Journal of Research in Commununication. 1(4), 275-301.

[46] Tsozué D, AzinwiTamfuh P, Ndaka Bonguen SM (2015) Morphology, Physicochemical Characteristics and Land Suitability in the Western Highlands of Cameroon. International Journal of Plant and Soil Science. 7, 29-44.https://doi.org/10.9734/IJPSS/2015/17147

[47] Tsozué D, Tematio P, Azinwi Tamfuh P (2016) Relationship between Soil Characteristics and Fertility Implications in Two Dystrandept Soils of the Cameroon Western Highland. International Journal of Soil Science. 11, 36-48.https://doi.org/10.3923/ijss.2016.36.48.

[48] Wafo GY (2016) Réponse à la croissance et à la productivité de deux variétés de maïs (ZeamaysL.) soumises à différentes doses de dolomie sur un Andosol leptique dans la Région de l'Ouest Cameroun : cas de Foumbot. Mémoire d'Ingénieur Agronome. FASA. Université de Dschang, Dschang.

[49] Walkey A, Black IA (1934) Determination of Organic Matter in Soil. Soil Science 37, 549-556.https://doi.org/10.1097/00010694-193401000$\underline{00003 .}$.

[50] Wandji P (1985) Contribution à l'étude pétrologique, géochimique et géotechnique des projections volcaniques de la région de Foumbot. Thèse doctorat 3ème cycle, Université de Yaoundé, Yaoundé.

[51] Xiao L, Sun Q, Yuan H, Li X, Chu Y, Ruan Y, Lu C \& Lian B. (2016). A feasible way to increase carbon sequestration by adding dolomite and K-feldspar to soil. Cogent Geoscience 2, 1-11https://doi.org/10.1080/23312041.2016.1205324.

[52] Velasquez PC J Lopes de souza C, Narro AL, Pandey S (2008) Genetic effects for maize traits in acid and non-acid soils. Genetics and Molecular Biology 31, 89-97.https://doi.org/10.1590/S1415-47572008000100017.

[53] Von Uexkull HR, Mutert E (1995) Global extent, development and economic impact of acid soils. Plant and Soil 171, 115.https://doi.org/10.1007/BF00009558. 